NBSIR 77-1196

\title{
Wind Tunnel Studies of RP-US Bayanihan Permanent School Building
}

R. D. Marshall

Structures Section

Center for Building Technology Institute for Applied Technology National Bureau of Standards

Washington, D.C. 20234

December 1977

Sponsored by

Office of Science and Technology

Agency for International Development

Department of State

Washington, D.C. 20523

Prepared for

U.S. Agency for International Development Manila, Philippines 

WIND TUNNEL STUDIES OF RP-US

BAYANIHAN PERMANENT SCHOOL BUILDING

R. D. Marshall

Center for Building Technology Institute for Applied Technology National Bureau of Standards

Washington, D.C. 20234

December 1977

Sponsored by

Office of Science and Technology

Agency for International Development

Department of State

Washington, D.C. 20523

Prepared for

U.S. Agency for International Development

Manila, Philippines

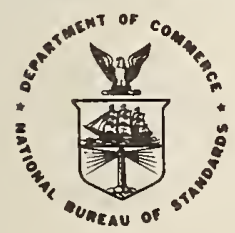

U.S. DEPARTMENT OF COMMERCE, Juanita M. Kreps, Secretary

Dr. Sidney Harman, Under Secretary

Jordan J. Baruch, Assistant Secretary for Science and Technology

NATIONAL BUREAU OF STANDARDS, Ernest Ambler, Acting Director 
In view of the present accepted practice in this country for building technology, common U.S. units of measurement have been used throughout this publication. In recognition of the position of the United States as a signatory to the General Conference on Welghts and measures, which gave officlal status to the metric SI system of units in 1960, appropriate conversion factors have been provided in the table below. The reader interested in making further use of the coherent system of SI units is referred to:

NBS SP 330, 1977 Edition, "The International System of Units"

ASTM E380-75/IEEE Std. 268-1976 ASTM/IEEE, "Standard Metric Practice Gulde"

Table of Conversion Factors to Metric (SI) Units

\begin{tabular}{|c|c|c|c|}
\hline $\begin{array}{l}\text { Physical } \\
\text { Quantity }\end{array}$ & $\begin{array}{l}\text { To Convert } \\
\text { From }\end{array}$ & To & Multiply By \\
\hline Leng th & $\begin{array}{l}\text { Inch ( } 1 n) \\
\text { foot (ft) }\end{array}$ & $\begin{array}{l}\text { meter }(\mathrm{m}) \\
\text { meter }(\mathrm{m})\end{array}$ & $\begin{array}{l}2.540 \times 10^{-2} * \\
3.048 \times 10^{-1} *\end{array}$ \\
\hline Area & $\begin{array}{l}\operatorname{lnch}^{2} \\
\text { foot }\end{array}$ & $\begin{array}{l}\text { meter }{ }^{2}\left(\mathrm{~m}^{2}\right) \\
\text { meter } \\
2\left(\mathrm{~m}^{2}\right)\end{array}$ & $\begin{array}{l}6.4516 \times 10^{-4} * \\
9.290 \times 10^{-2}\end{array}$ \\
\hline Volume & $\begin{array}{l}\text { Inch }^{3} \\
\text { foot }^{3}\end{array}$ & $\begin{array}{l}\operatorname{meter}^{3}\left(\mathrm{~m}^{3}\right) \\
\operatorname{meter}^{3}\left(\mathrm{~m}^{3}\right)\end{array}$ & $\begin{array}{l}1.639 \times 10^{-5} \\
2.832 \times 10^{-2}\end{array}$ \\
\hline Force & pound ( $1 \mathrm{bf}$ ) & newton (N) & 4.448 \\
\hline Pressure or Stress & $\begin{array}{l}\text { psi } \\
\text { psf }\end{array}$ & $\begin{array}{l}\text { pascal }(\mathrm{Pa}) \text { or } \\
\text { newton } / \text { meter }^{2}\left(\mathrm{~N} / \mathrm{m}^{2}\right)\end{array}$ & $\begin{array}{l}6.895 \times 10^{3} \\
4.788 \times 10^{1}\end{array}$ \\
\hline Mass & pound $(1 \mathrm{bm})$ & kilogram $(\mathrm{kg})$ & $4.536 \times 10^{-1}$ \\
\hline Unit Welght & pcf & kilogram/meter ${ }^{3}\left(\mathrm{~kg} / \mathrm{m}^{3}\right)$ & $1.602 \times 10^{1}$ \\
\hline Velocity & $\mathrm{mile} / \mathrm{hr}$ (mph) & meter/sec $(\mathrm{m} / \mathrm{s})$ & $4.470 \times 10^{-1}$ \\
\hline Acceleration & $\mathrm{foot} / \mathrm{sec}^{2}$ & meter $/ \mathrm{sec}^{2}\left(\mathrm{~m} / \mathrm{s}^{2}\right)$ & $3.048 \times 10^{-1}$ \\
\hline
\end{tabular}

*Exact value 

Wind Tunnel Studies

of

RP-US Bayanihan Permanent School Bullding

by

Richard D. Marshall

\begin{abstract}
Wind pressures measured on a 1:80 scale model of the RP-US Bayanthan Permanent School Bulling are compared with wind pressures used in the original design calculations. The wind tunnel studies were conducted in a tunnel fitted with spires and roughness elements to generate a thick, turbulent boundary layer. This boundary layer is belleved to be a reasonable simulation of the lowest portion of the atmospheric surface layer developed over rolling countryside with scattered trees or over suburban areas. While the wind tunnel test results are in fair agreement with the overall design wind pressures, edges of the roof along the end walls can be subjected to pressures which substantially exceed the design values. It is recommended that the load capacity of certain roof elements be reexamined and that ridge ventilators be used in future eonstruction to reduce the uplift loads on the roof structure.
\end{abstract}



SI CONVERSION UNITS ......................... 111

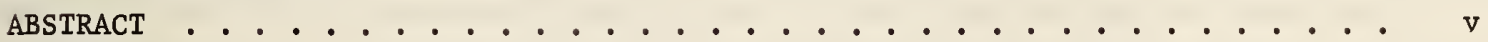

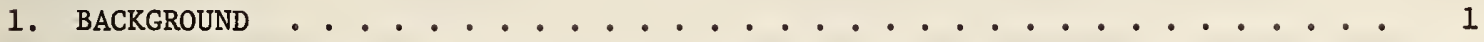

2. THE UNIVERSITY OF THE PHILIPPINES WIND TUNNEL . . . . . . . . . . . 2

3. THE WIND TUNNEL MODEL . . . . . . . . . . . . . . . . . 2

4. COLLECTION AND ANALYSIS OF DATA . . . . . . . . . . . . . . 3

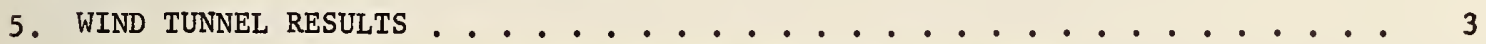

6. COMPARISON OF WIND TUNNEL RESULTS AND ACTUAL DESIGN LOADS . . . . . . . . 4

7. THE EFFECT OF SURFACE ROUGHNESS . . . . . . . . . . . . . . 6

8. CONCLUSIONS AND RECOMMENDATIONS . . . . . . . . . . . . . . 7

8.1 0verall Pressures . . . . . . . . . . . . . . . 7

8.2 Pressures on Tributary Areas . . . . . . . . . . . . . 7

8.3 Choice of Design Speed . . . . . . . . . . . . . . 7

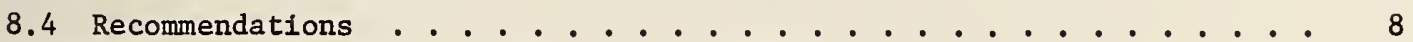

9. ACKNOWLEDGMENTS . . . . . . . . . . . . . . . . 8

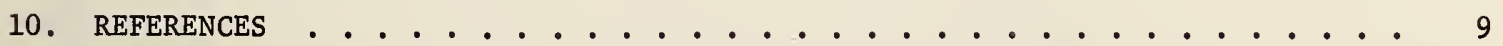





\section{BACKGROUND}

Following the destructive typhoons of September - November 1970, in which an estimated 7,000 public school classrooms were destroyed, the Government of the Philippines established an emergency school rehabilitation committee which subsequently became the RP-US Bayanihan (Self-Help) School Reconstruction Committee. Since its inception in 1971, the committee has been responsible for the construction of more than 500 school buildings under an initial construction program funded in large part by USAID appropriations. A second phase, Bayanihan II, was initiated after the Central Luzon floods of 1972 with the goal of constructing an additional 1,000 school buildings by 1975. The basic school building contains three classrooms and is approximately $26 \times 59 \mathrm{ft}(8 \times 18 \mathrm{~m})$ in plan. The structural system consists of reinforced concrete grade beams, columns and ring beams with reinforced concrete masonry infill walls. The gabled roof structure is a system of timber purlins and roof trusses with crossbracing. Corrugated galvanized iron (CGI) sheet and wood sheathing make up the roof deck. The design wind loads were based on a wind speed of $140 \mathrm{mph}(63 \mathrm{~m} / \mathrm{s})$.

In early 1973, the Agency for International Development requested the National Bureau of Standards, under a Participating Agency Service Agreement (PASA), to develop improved design criteria for low-rise, low-cost buildings to better withstand extreme winds. An important part of this project was the documentation of wind forces by direct measurement on full-scale buildings and the correlation of these measurements with results obtained from wind tunnel model studies. The decision was made in the early stages of this project to conduct the fullscale studies in the Philippines since Luzon has the world's highest frequency of tropical storms. It was also decided to conduct certain wind tunnel studies at the University of the Philippines as a lowspeed tunnel was avallable which, with some modifications, could be used for research into building aerodynamics. The purpose of these studies was to provide guidance for the placement of pressure transducers on the full-scale test buildings and to aid in the interpretation of full-scale data. Accordingly, modifications to the UP wind tunnel facility were made and the instrumentation of full-scale test buildings was initiated in September of 1973. By July of 1974, the training of personnel and the installation of wind tunnel test equipment had reached a point where atmospheric surface flows could be simulated to a satisfactory degree and correlation studies were made to demonstrate the validity of the model test results. A local capability had thus been established to carry out model studies of wind forces on buildings.

At the request of the AID Mission in Manila, arrangements were made to conduct a series of tests in the UP wind tunnel facility on a model of the RP-US Bayanihan school building. The tests were conducted over a two-week period in November, 1974, the principal objectives being the evaluation of the original wind-load design criteria and the possible refinement of design loads for future construction. The following sections of this report contain a description of the wind tunnel studies, the analysis of test results and a comparison of these results with the original design loads. 
The University of the Philippines lowspeed wind tunnel facility was constructed approximately 20 years ago with USAID funds and was intended for instruction in basic aerodynamics. The test section is $4 \times 4 \mathrm{ft}(1.2 \times 1.2 \mathrm{~m})$ with a length of $12 \mathrm{ft}(3.7 \mathrm{~m})$. It is a closedreturn tunnel with a variable-speed drive and has a large contraction ratio to produce flows of low turbulence. The original test section was equipped with corner fillets to reduce secondary flows and as such, was well-suited for aeronautical work. Modifications for this project included: (1) removal of the corner fillets to provide a wider floor and increased flow area, (2) extension of the test section into the diffuser to increase its effective length, (3) installation of spires to produce an initial sheared flow and, (4) introduction of roughness elements on the floor to generate a thick, turbulent boundary layer for simulation of both the mean and fluctuating components of the natural wind. A turntable was also installed at the downstream end of the test section on which building models can be mounted and rotated to change the relative wind direction.

Test equipment provided for the facility under this project included hot-wire anemometers to measure mean air speeds and turbulence, pressure transducers to measure both mean and fluctuating pressures acting on the surfaces of models, various instruments for the monitoring and conditioning of signals, signal analysis equipment and recording equipment. It was thus possible to perform most of the data analysis "on line" while the tests were being conducted.

\section{THE WIND TUNNEL MODEL}

Based on flow characteristics measured in the wind tunnel boundary layer and measurements obtained in full-scale studies, the scale ratio of the wind tunnel flow is believed to be approximately 1:150. That is to say, any characteristic dimension in the real case should be made 150 times smaller in the wind tunnel model to properly simulate the flow around a building. However, there is a practical limit to the scale ratio since the model must be of sufficient size to include all of the pertinent physical features of the building and to also provide sufficient space to install the pressure transducers or sensors. These requirements dictated a model scale of not less than 1:80. Previous tests had shown reasonable agreement between full scale and model using this scale ratio.

The model was equipped with fifteen pressure taps and four pressure transducers. Wind speeds were measured by means of a hot-wire anemometer placed just upstream and to the side of the model where flow conditions were representative of the undisturbed wind field. The height of the anemometer above the floor was 4.92 in $(125 \mathrm{~mm})$ which corresponds to the standard anemometer height of $10 \mathrm{~m}$ in full scale. The pressure measurements were referenced to the ambient pressure in the wind tunnel at this same height and the model was positioned $15 \mathrm{ft}(4.6 \mathrm{~m})$ downstream from the entrance to the test section. Dimensions of the model were scaled from drawings of the Type 1-Wb school building provided by the Philippine Bureau of Public Works. 
The model was constructed of plexiglass sheets and the pressure taps were connected to the transducers by short lengths of flexible tubing. This allowed the simultaneous measurement of pressures at any four pressure taps on the model and frequencies as high as $120 \mathrm{~Hz}$ could be measured without appreciable distortion. A drawing of the model and the location of pressure taps are shown in figure 1. No attempt was made to simulate infiltration (flow through the building) and thus no meaningful measurements of internal pressures could be made.

\section{COLLECTION AND ANALYSIS OF DATA}

As indicated above, the test equipment allowed for "on line" analysis of most of the data. The calculation of pressure coefficients was carried out after the tests had been completed. The mean wind speed at the scaled height of $10 \mathrm{~m}$ was $26 \mathrm{fps}(7.9 \mathrm{~m} / \mathrm{s})$ and the intensity of turbulence at this height was approximately 25 percent. This was the maximum speed that could be attained without encountering bothersome vibrations in the drive motor and fan assembly. The mean velocity profile over the range of interest is best described by a power law with an exponent $\alpha=0.3$ which suggests either a terrain roughness typified by rolling countryside with scattered trees or suburban areas.

Pressure signals were analyzed for mean, root-mean-square (rms), and peak departures from the mean. The first two quantities were determined by voltmeter measurements and peak values were obtained by two methods: visual observation of a 30-second stripchart recording, and a display of the probability density function. The procedure for obtaining pressure data was to rotate the model until selected pressure taps indicated maximum pressure fluctuations. The critical wind directions were then investigated in detail, using single channels of data and also electronically adding or summing combinations of channels in groups of 2 to determine the effectiveness of pressure fluctuations acting over extended roof and wall areas.

\section{WIND TUNNEL RESULTS}

Although many pressure measurements were obtained during the course of these tests, only a limited number represented critical conditions and were thus of interest in establishing design pressure coefficients. Pressure taps 3 and 8 were found to be unreliable and readings from these had to be discarded. The remaining taps did, however, provide sufficient information to determine the average and peak pressures acting over both localized and extended areas with a fair degree of accuracy.

Prior to discussing the test results, it is necessary to define some terms used to present the test data. Figure 2 shows an idealized time history of a pressure signal. The quantities of interest are the mean pressure $\bar{P}$, the standard deviation or root-mean-square of the fluctuations about the mean, $P_{\text {rms }}$, and the maximum and minimum pressures $P_{\max }$ and $P_{\text {min }}$ observed over a specified time interval. In this case the time interval was 30 seconds which would correspond to approximately 10 minutes in the ful1-scale case, assuming a peak wind speed of 140 $\mathrm{mph}(63 \mathrm{~m} / \mathrm{s})$ averaged over 2 seconds. The peak departures from the mean (algebraic difference 
between $\mathrm{P}_{\max }$ or $\mathrm{P}_{\min }$ and the mean, $\overline{\mathrm{P}}$ ) are expressed in terms of a coefficient $\mathrm{g}$, called the peak factor, which is obtained by dividing the absolute value of the peak departure by the root-mean-square of the fluctuations,

$$
g=\frac{\mid \mathrm{P}_{\max } \text { or min }-\overline{\mathrm{P}} \mid}{\mathrm{P}_{\text {rms }}}
$$

For a normal or gaussian process, one would expect values of $g$ in the range of 3.5 to 4 . As will be seen, the pressure fluctuations are definitely not gaussian and much higher values of $g$ are encountered.

For convenience in the subsequent application of test results, pressures (which were originally measured in volts) are normalized by the mean dynamic pressure $q$ at the standard reference height of $4.92 \mathrm{in}(125 \mathrm{~mm})$ in the wind tunnel. The resulting pressure coefficients can then be used directly for full-scale applications once the design wind speed is established. The expressions for the coefficients and peak pressures are:

$$
\begin{aligned}
& C_{p}=\bar{P} / q \\
& C_{p f}=P_{r m s} / q \\
& P_{\text {max }}=q\left(C_{p}+g C_{p f}\right) \\
& P_{\text {min }}=q\left(C_{p}-g C_{p f}\right)
\end{aligned}
$$

The critical pressure measurements and resulting coefficients are listed in tables 1 and 2 . Refer to figure 1 for pressure tap locations and relative wind directions. A close look at table 1 reveals that the magnitudes of the peak departures $\left(\mathrm{g} \mathrm{C}_{\mathrm{pf}}\right.$ ) generally exceed those of the means and the peak factors are substantially greater than expected for a normally distributed random variable. The same is true for table 2 wherein the signals from two pressure taps were combined or summed prior to being analyzed. Maximum and minimum values of $C_{p}+g C_{p f}$ and $C_{p}-g C_{p f}$ for observed values of $g$ and for $g=4.0$ are listed in table 3 .

\section{COMPARISON OF WIND TUNNEL RESULTS AND ACTUAL DESIGN LOADS}

The pressure coefficients of table 3 have been rounded off and combined to give the expected maximum (mean + fluctuating component) and are presented in figures 3 and 4 according to area of application. They represent "worst case" situations as revealed by the model test results. Figure 3 gives coefficients for determining the overall wind loading while figure 4 presents coefficients to be used in determining loads on localized or tributary areas $\left(5 \mathrm{~m}^{2}\right.$ or less). As mentioned earlier, no attempt was made to measure pressures inside the model since this would have required proper simulation of the infiltration. Experimental data collected 
from several full-scale tests suggest that pressure coefficients over the range 0.4 to -0.2 can be expected for well-ventilated buildings such as the RP-US Bayanihan school building and these coefficients have been used in determining the critical pressure distributions.

Since the reference wind speed in the wind tunnel was averaged over a sufficiently long time period to obtain a stable mean, it is important that the resulting pressure coefficients be used with design wind speeds similarly averaged. Experience gained from the analysis of many wind records suggests that 1000 seconds is a suitable averaging period. It is equally important that the pressure coefficients be used with the wind speed at a height of $10 \mathrm{~m}$ since this is the speed upon which they are based.

The design speed used for the RP-US Bayanthan school building was $140 \mathrm{mph}(63 \mathrm{~m} / \mathrm{s})$. Although not specifically stated in any of the design documentation, it is assumed that this refers to the $10 \mathrm{~m}$ height in flat open country and an averaging time of approximately 2 seconds, this being the accepted maximum response of typical 3-cup anemometers. To convert this to a speed averaged over 1000 seconds, reference is made to figure 5 which represents peak wind speeds for various averaging times as a ratio of the 1000-second average. This curve is based on data obtained at Laoag City during 1974 and agrees quite well with results obtained at other test sites in the Philippines. The corresponding wind speed for a 1000-second averaging period is $82 \mathrm{mph}(37 \mathrm{~m} / \mathrm{s})$. Critical or worst-case pressure combinations for the walls and roof sections are determined on Computation Sheet No. 1 while the critical cases for tributary areas are determined on Computation Sheet No. 2. The "side wall" designation indicates that the wind direction is parallel to it. Thus, a wall can be a windward, leeward or side wall, depending upon wind direction. It should be pointed out that negative signs indicate outward pressures or uplift and that the choice of internal pressure is always based on worst-case conditions. For uplift on the roof overhangs, it is assumed that the pressure on the windward wall also acts on the underside of the overhang.

Pressures acting on tributary areas are not to be used in calculating loads acting on the overall structure. They allow for pressure fluctuations caused by flow separation around corners, ridges and eaves and by incident turbulence in the oncoming flow. Also, peak pressures acting on tributary areas should not include the overall pressures, but should include the internal pressures. This is because the overall pressures have been accounted for in the determination of the peak pressure coefficients. It will be noticed that a pressure coefficient of +1.0 has been used to calculate the peak uplift pressures on the roof overhangs (Computation Sheet No, 2). This is due to the fact that the peak suction pressures occur for wind blowing obliquely, rather than face-on, allowing a reduction in the pressure coefficient under the overhang. It should also be observed that peak uplift pressures acting on the CGI sheet do not include internal pressure while those acting on the wood sheathing do. This is because the major portion of the pressure change (internal to external) can be expected to occur across the sheathing, rather than across the CGI sheet. 
Overall pressures on which to base total drag and uplift loads for the case of wind blowing perpendicular to the ridge of the roof are shown in figure 6a. The internal pressures are shown applied to the roof only since they produce no net drag force in the direction of the wind. Pressure distributions used in the original design calculations are shown in figure $6 \mathrm{~b}$. It should be noted that these calculations were for a preliminary scheme using a prestressed concrete roof and might not represent the pressure distributions used in the final design which consists of a timber roof structure. No design calculations were obtainable with which to compare pressures acting on tributary areas or the overall pressures for wind blowing along the ridge.

For the case presented in figures $6 \mathrm{a}$ and $6 \mathrm{~b}$, the original design loads acting in the direction of the wind (drag) are approximately 50 percent greater than those based on the wind tunnel tests while the roof uplift loads are about 20 percent less, mainly due to neglecting internal pressures.

\section{THE EFFECT OF SURFACE ROUGHNESS}

The effect of increased surface roughness such as hills, trees and other buildings is generally to reduce the wind speeds that would otherwise be observed in flat, open country under identical meteorological conditions. A discussion of wind speed profiles for various surface or terrain conditions and some techniques for relating winds in different roughness regimes are presented in Ref. 1. As indicated previously, the mean velocity profile established in the wind tunnel could be represented by a power law with an exponent of 0.3 . This corresponds approximately to a surface roughness length of $0.4 \mathrm{~m}$ in full scale.

To illustrate the effect of surface roughness on design loads, three categories of roughness are considered in table 4. These categories can be described as follows:

$\begin{array}{ll}\text { Roughness Length, } Z_{0} \text { (meters) } & \text { Description } \\ 0.08 & \text { Flat, open country } \\ 0.20 & \text { Short trees and brush } \\ 0.50 & \begin{array}{l}\text { Hills and trees, heavily } \\ \text { built-up residential areas }\end{array}\end{array}$

A range of speeds from 80 to $160 \mathrm{mph}$ ( 36 to $72 \mathrm{~m} / \mathrm{s}$ ), based on a 1 -minute average at $10 \mathrm{~m}$, is assumed for flat, open country and these speeds are then converted to 1,000-second averages for the three roughness categories using the procedure described in Ref. 1 (see worked example in table 4). The mean dynamic pressures are calculated and applied to the pressure coefficients for determining roof uplift on the windward side. The dashed horizontal lines in table 4 indicate the point at which the original design pressure of $19.9 \mathrm{psf}\left(950 \mathrm{~N} / \mathrm{m}^{2}\right)$ is exceeded. 


\section{CONCLUSIONS AND RECOMMENDATIONS}

\subsection{Overal1 Pressures}

Based upon an assumed design speed of $140 \mathrm{mph}(63 \mathrm{~m} / \mathrm{s})$ at the $10-\mathrm{m}$ height and averaged over 2 seconds, the wind tunnel test results for the roof agree well with the overall pressures used in the original design calculations. Even though the internal pressures appear to have been neglected in the original calculations for estimating the total roof uplift, the differences are not significant when compared to the uncertainty in selecting an appropriate design wind speed.

\subsection{Pressures on Tributary Areas}

In view of the type of construction used in the walls, windows, etc., it is very doubtful that the peak pressures acting on tributary wall areas are any cause for concern, even though they might not have been specifically considered in the original design. There is, however, sufficient justification for checking the load capacity of the roof overhang directly above the end walls (90-degree elevation) and the wood sheathing and CGI sheet over the entire roof because of the relatively higher loads acting on tributary areas. That the edge of the roof along the end walls is the area of maximum uplift has been confirmed time and again by surveys of wind damage. Should subsequent evaluation of the wood sheathing and CGI sheet indicate underdesign, a retrofit by increased nailing or by the use of battens should be considered.

\subsection{Choice of Design Speed}

In assessing the wind loads on the RP-US Bayanihan school building, it has been assumed that the design wind speed was $140 \mathrm{mph}(63 \mathrm{~m} / \mathrm{s})$, referenced to the $10-\mathrm{m}$ height and averaged over 2 seconds. The corresponding 1-minute average (see Figure 5) is $100 \mathrm{mph}$ (45 $\mathrm{m} / \mathrm{s}$ ). The fact that the dynamic pressure based on $140 \mathrm{mph}$ was used in the original calculation of the overall pressures could also imply a 5-second averaging time for the design speed since this gust duration is widely used for calculating overall pressures. The corresponding 1-minute average would be $108 \mathrm{mph}(48 \mathrm{~m} / \mathrm{s})$. These 1 -minute averages allow one to compare the actual design speed with extreme wind speeds over Luzon for various mean recurrence intervals, the average number of years over which the associated speed has a specified probability of being exceeded at least once. Reference is made to table 5 which has been extracted from Ref. 2. For comparison, the 1-minute speeds of 100 and $108 \mathrm{mph}$ (45 and $48 \mathrm{~m} / \mathrm{s}$ ) are converted to knots; 86 and $93 \mathrm{kts}$, respectively.

The choice of mean recurrence interval involves two main factors; (1) the consequences of catastrophic failure (total collapse) and (2) cost of construction. Although the Bayanihan school buildings will be occupied only some 20 percent of the time, it is quite 
likely that they will in many cases serve as community typhoon shelters. This would suggest a 50-year mean recurrence interval at the very least. As can be seen from table 5, these speeds are substantially exceeded along the east coast of Luzon, in parts of the Bicol, and in the Manila area. The speeds presented in table 5 are open to some question because the data series were not in all cases reduced to standard terrain conditions, i.e., flat, open country. Work currently being carried out under the NBS-USAID project and employing refined methods of analysis is expected to result in slightly different distributions of extreme winds. At any rate, the wind speed associated with the ultimate load capacity of the structure should be evaluated, making proper allowance for terrain roughness as indicated in table 4, and compared with the speeds of table 5 or the latest available distributions.

\subsection{Recommendations}

Based on data presented in this report and information obtained from other sources, the following steps in the evaluation of the RP-US Bayanihan design are recommended:

1. Calculate the collapse load for the final RP-US Bayanihan design using the pressure coefficients obtained from the wind tunnel tests, determine the corresponding 1000-second average speed and the 1-minute average speed, and compare this with the latest available distributions of extreme speeds. Although major changes in the structural system are out of the question, this will provide some measure of the risk of failure.

2. Using the 1000 -second average speed of $82 \mathrm{mph}(37 \mathrm{~m} / \mathrm{s})$, compare the loadings on the tributary roof areas with the probable load capacity of the roofing elements and retrofit as required and if economically feasible. Where appropriate, reductions in wind speed due to terrain roughness can be made.

3. Give serious consideration to additional wind tunnel studies if size or shape of new school construction differs significantly from the structure discussed in this report.

4. Explore the possibility of installing ridge ventilators in future school buildings. The roof ridge is always a low-pressure region and venting will create negative internal pressures, thus reducing uplift loads on the roof elements.

\section{ACKNOWLEDGMENTS}

Mr. P. Castro and Mr. S. Coran of the University of the Philippines supervised construction of the building model and assisted the author during the course of the wind 
tunnel studies. Dr. E. Simiu of the Center for Building Technology, National Bureau of Standards, provided many useful comments and suggestions during the preparation of this report.

\section{REFERENCES}

1. Simiu, Em1l "Logarithmic Profiles and Design Wind Speeds." Journal of the Engineering Mechanics Division, ASCE, Vo1. 99, No. EM5, Proc. Paper 10100, October 1973, pp. 1073-1083.

2. Kintanar, Roman L., "Climatology and Wind-Related Problems in the Philippines." Proceedings of a Workshop on Design for Extreme Winds, Building Science Serles 56, National Bureau of Standards, Washington, D. C., October 1974. 


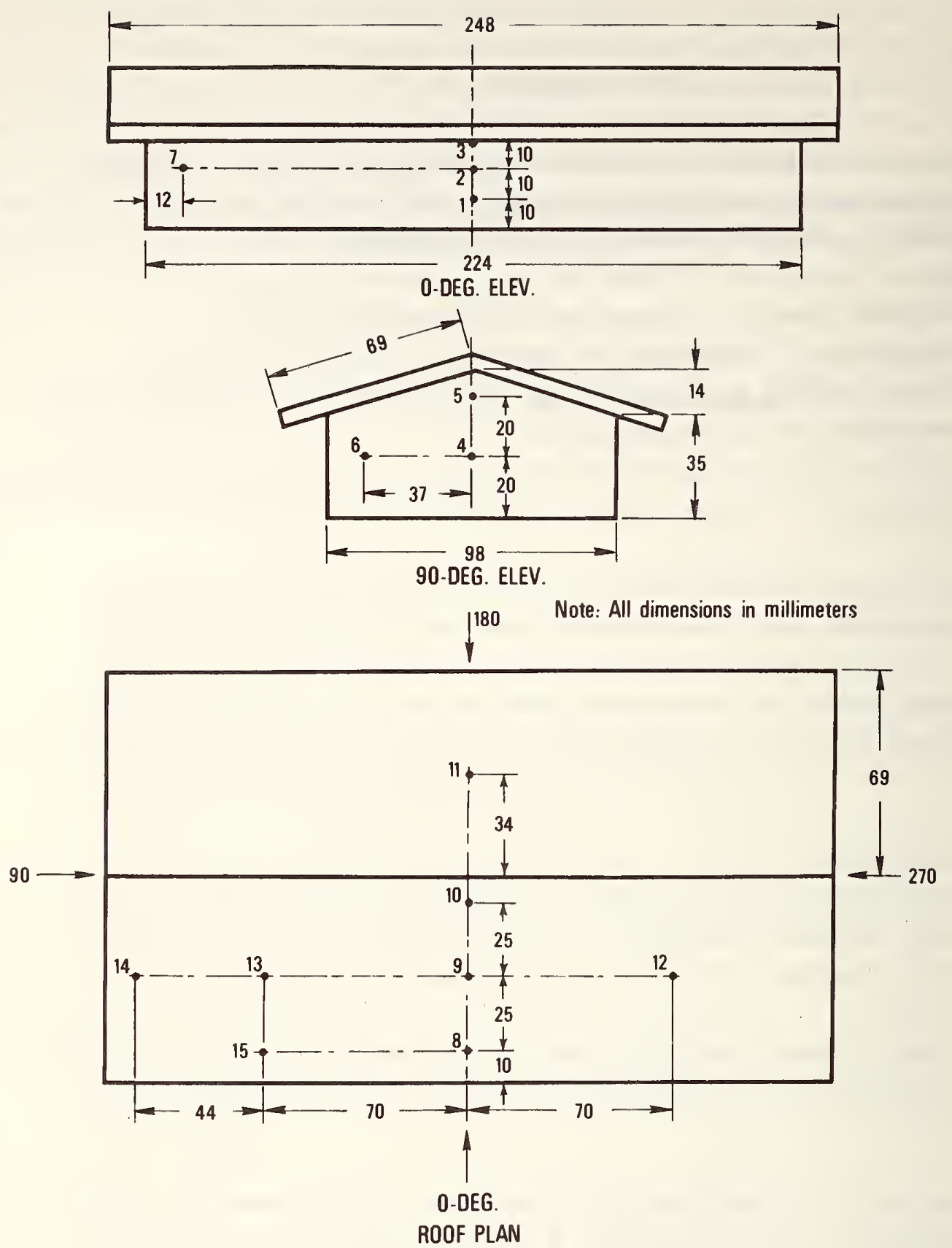

Figure 1 - Pressure Tap Locations (1:80 scale) 


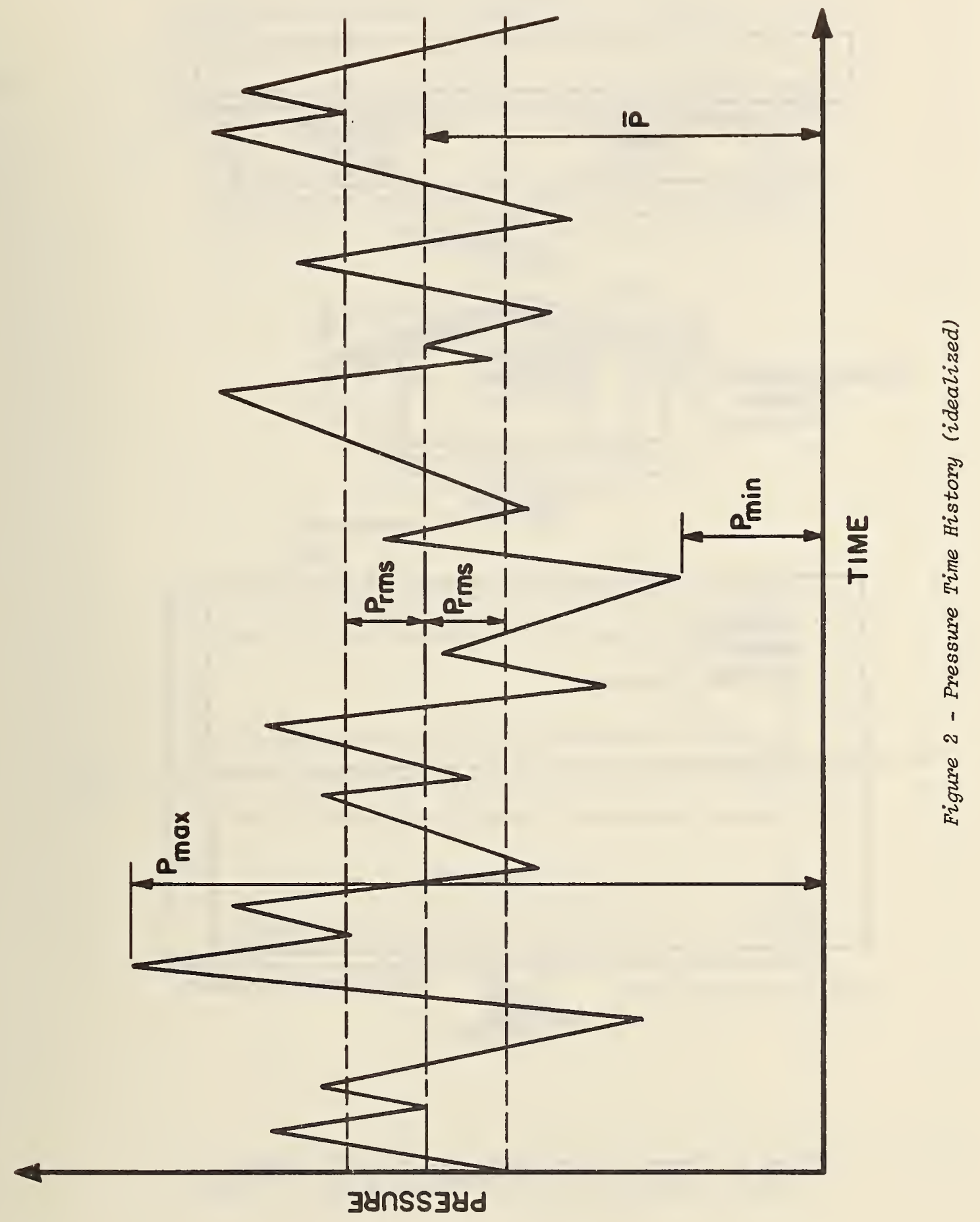




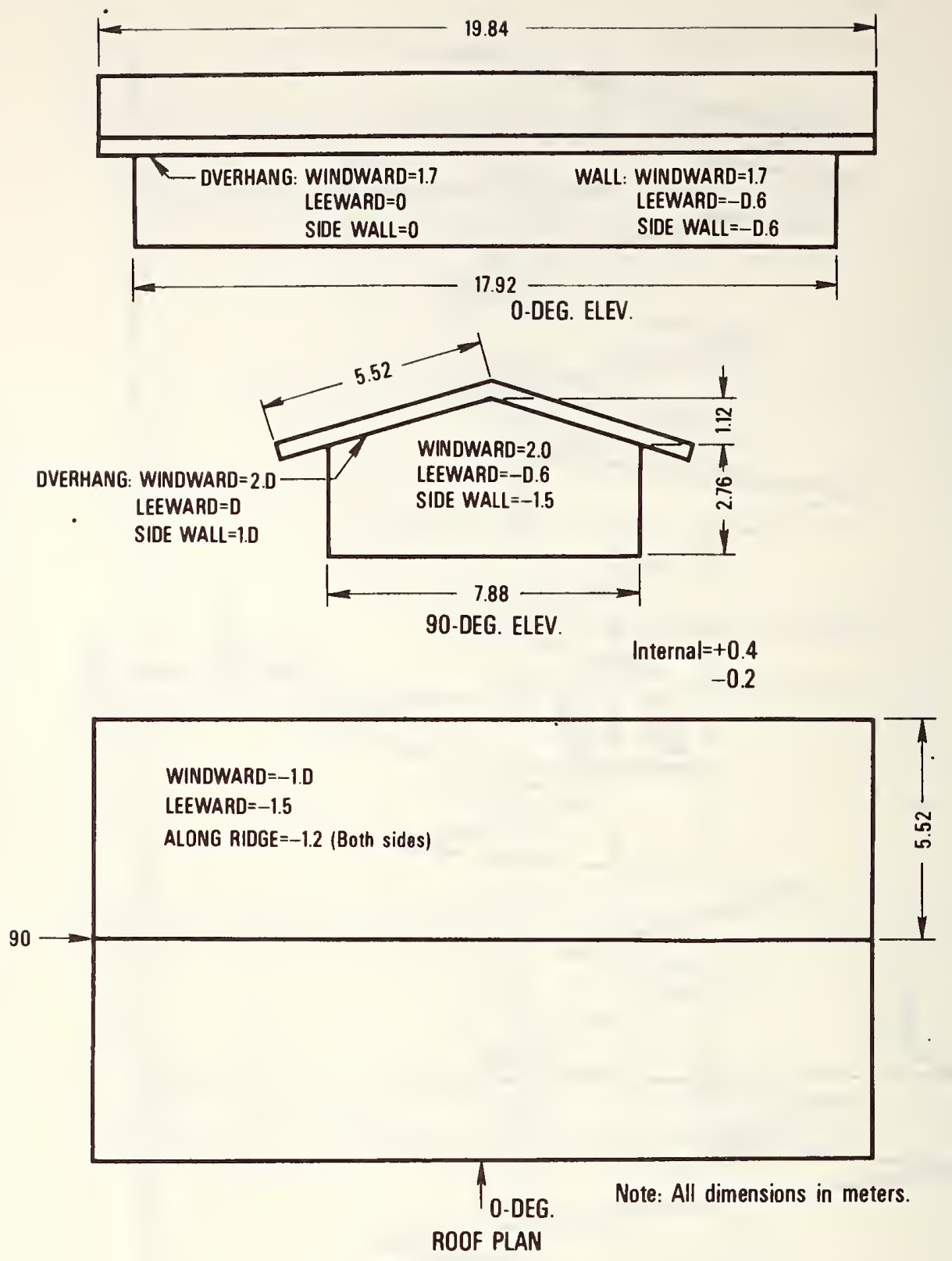

Figure 3 - Pressure Coefficients for Overall Loading 

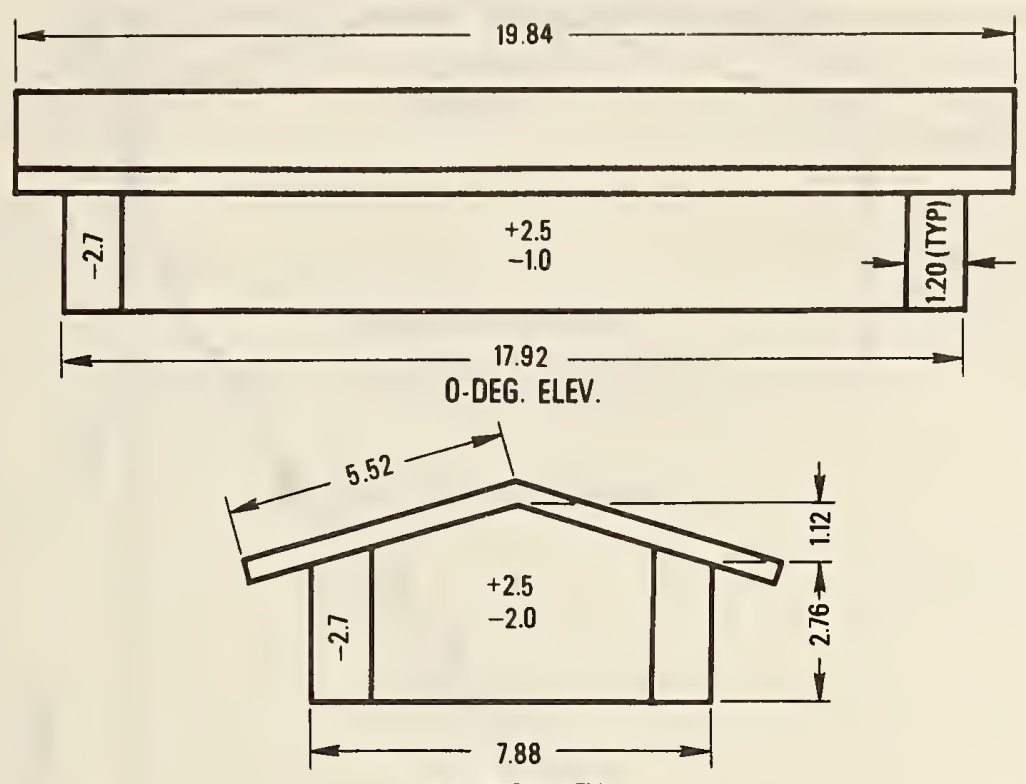

90-DEG. ELEV.

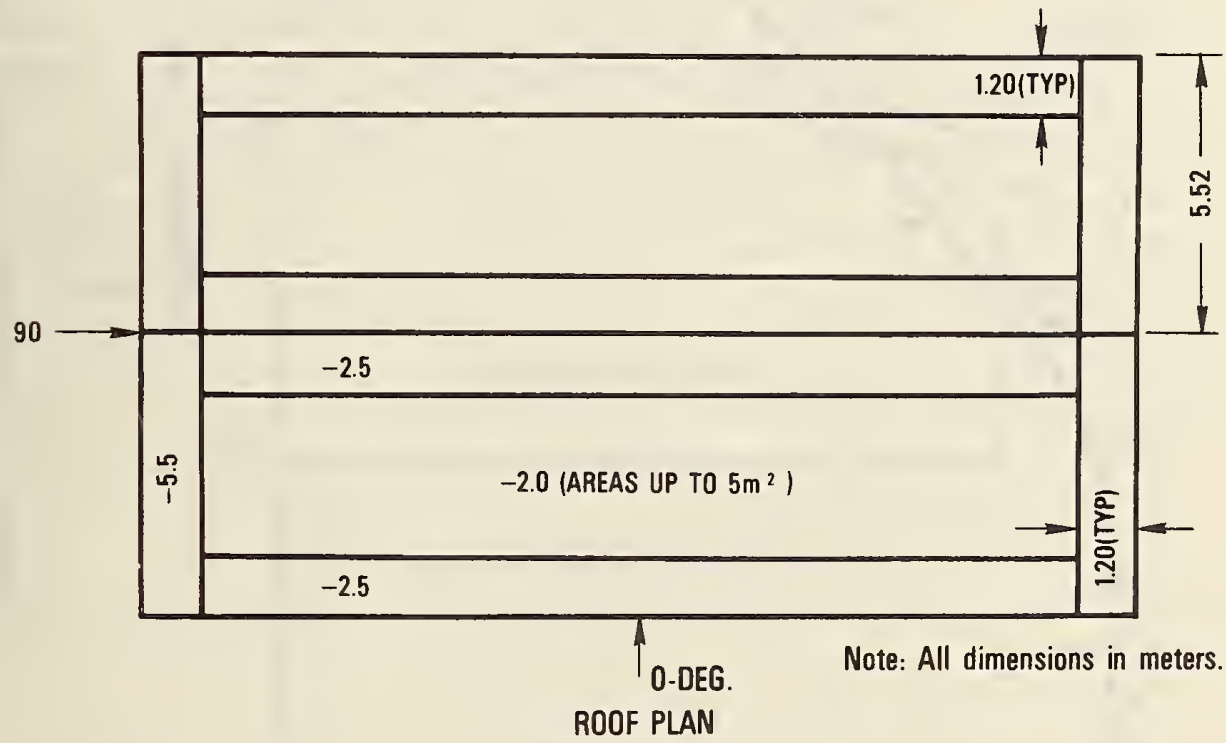

Figure 4 - Pressure Coefficients for Localized Loading 


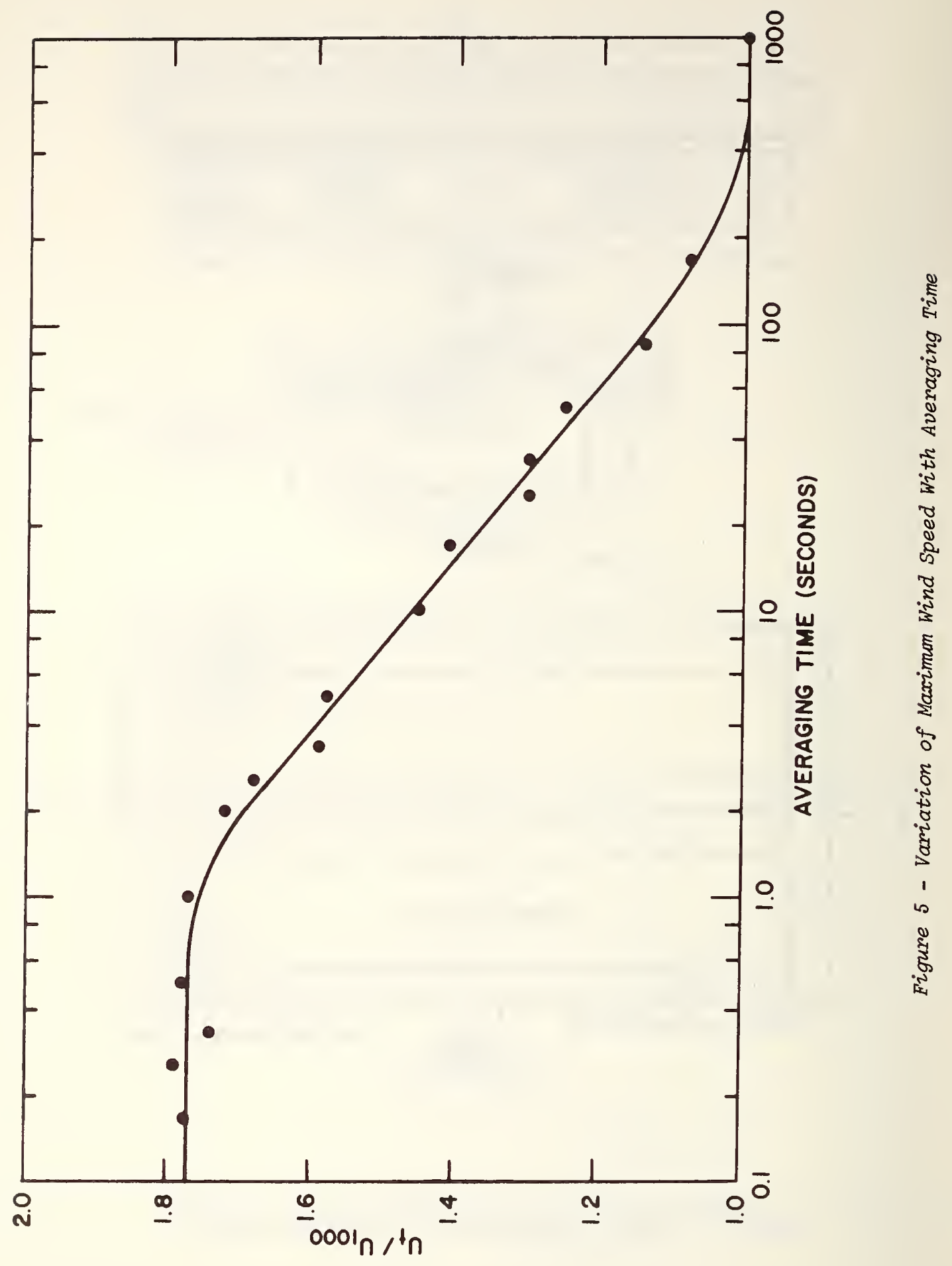




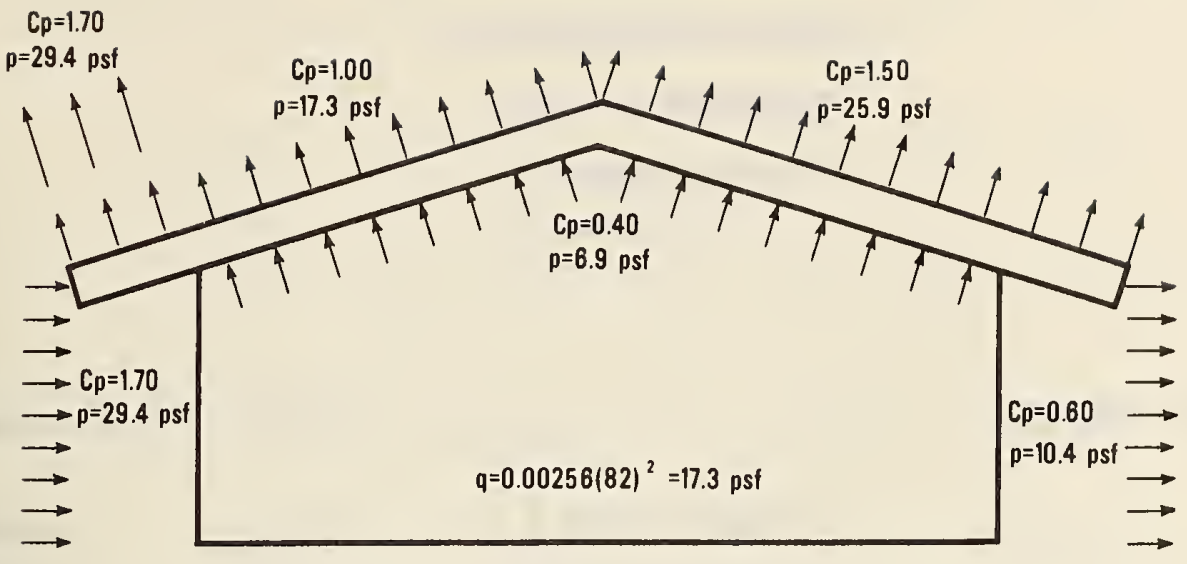

(a) Wind Tunnel Results

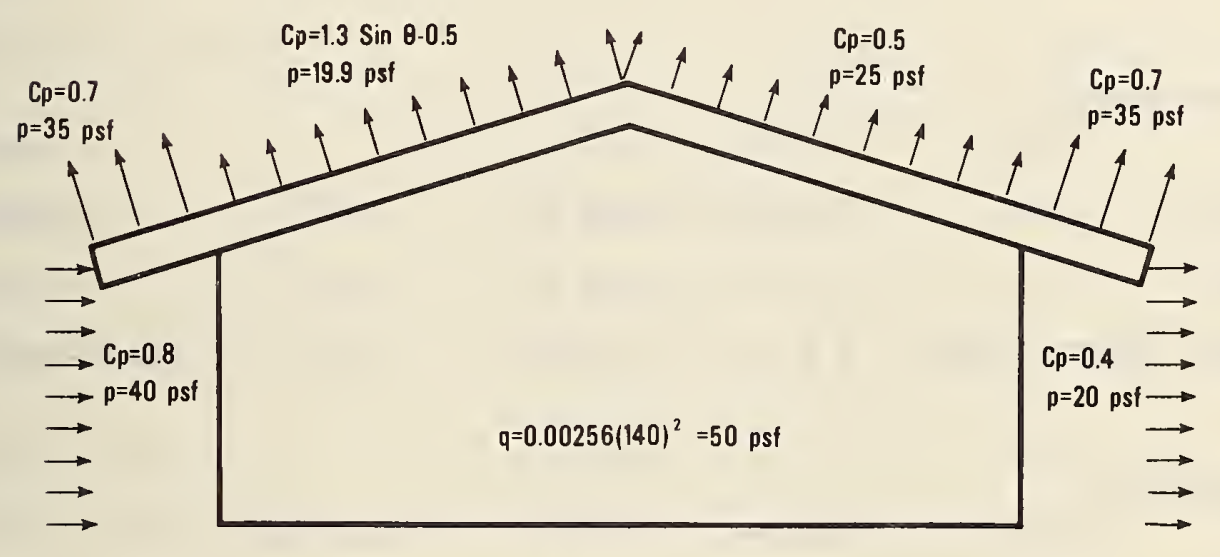

(b) Original Design Pressures

Figure 6 - Comparison of Overall Loading 
COMPUTATION SHEET NO. 1

Worst-Case Loading

Extended Areas

0-Deg. Elev. (Side wall)

(psf)

$\left(\mathrm{N} / \mathrm{m}^{2}\right)$

Inward:

$P=(1.7+0.2) q=$

32.9

1570

Outward:

$P=(-0.6-0.4) q=$

$-17.3$

$-830$

90-Deg. Elev. (End wal1)

Inward:

$P=(2.0+0.2) q=$

38.1

1820

Outward:

$P=(-1.5-0.4) q=$

$-32.9$

$-1570$

Roof - Wind Normal to Ridge

Windward side:

$P=(-1.0-0.4) q=$

$-24.2$

$-1160$

Leeward side:

$P=(-1.5-0.4) q=$

$-32.9$

$-1570$

Roof overhang (0-Deg. Elev.):

$P=(-1.0-1.7) q=$

$-46.7$

$-2240$

Roof - Wind Along Ridge

Both roof slopes:

$P=(-1.2-0.4) q=$

$-27.7$

$-1330$

Roof overhang (90-Deg. Elev.): $\quad P=(-1.2-2.0) q=$

$-55.4$

$-2650$

$\mathrm{q}=17.3 \mathrm{psf}$ 
COMPUTATION SHEET NO. 2

Worst-Case Loading

Tributary Areas

(Area $\leq 5 \mathrm{~m}^{2}$ )

Corners of Walls

(psf)

$\left(\mathrm{N} / \mathrm{m}^{2}\right)$

Outward:

$P=(-2.7-0.4) q=$

$-53.6$

$-2570$

0-Deg. Elev. (Side wall)

Inward:

$P=(2.5+0.2) q=$

46.7

2240

Outward:

$P=(-1.0-0.4) q=$

$-24.2$

$-1160$

90-Deg. Elev. (End wall)

Inward:

$P=(2.5+0.2) q=$

46.7

2240

Outward:

$P=(-2.0-0.4) q=$

$-41.5$

$-1990$

Roof - Wood Sheathing

Strips along ridge:

$P=(-2.5-0.4) q=$

$-50.2$

$-2400$

Roof overhang (0-Deg. Elev.):

$P=(-2.5-1.0) q=$

$-60.6$

$-2900$

"

" (90-Deg. Elev.):

$P=(-5.5-1.0) q=$

$-112.5$

$-5380$

All other roof areas:

$\mathrm{P}=(-2.0-0.4) \mathrm{q}=$

$-41.5$

$-1990$

Roof - CGI Sheet

$\begin{array}{ll}\text { Strips along ridge: } & P=-2.5 q= \\ \text { Roof overhang (0-Deg. Elev.): } & P=-2.5 q= \\ " \quad " \quad(90-\text { Deg. Elev.): } & P=-5.5 q= \\ \text { All other roof areas: } & P=-2.0 q=\end{array}$

$-43.3$

$-2070$

$-43.3$

$-2070$

$-95.2$

$-4560$

$-34.6$

$-1660$ 


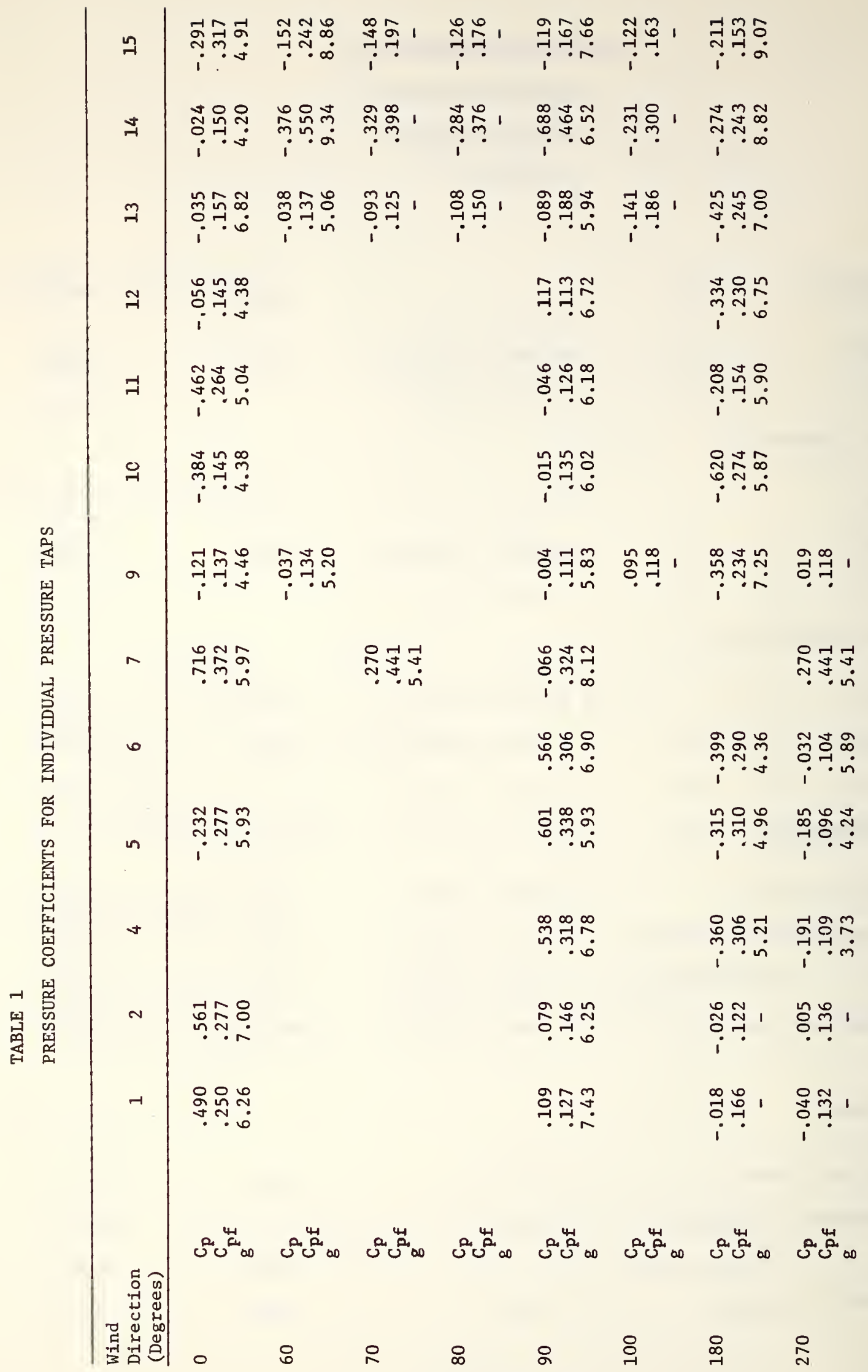




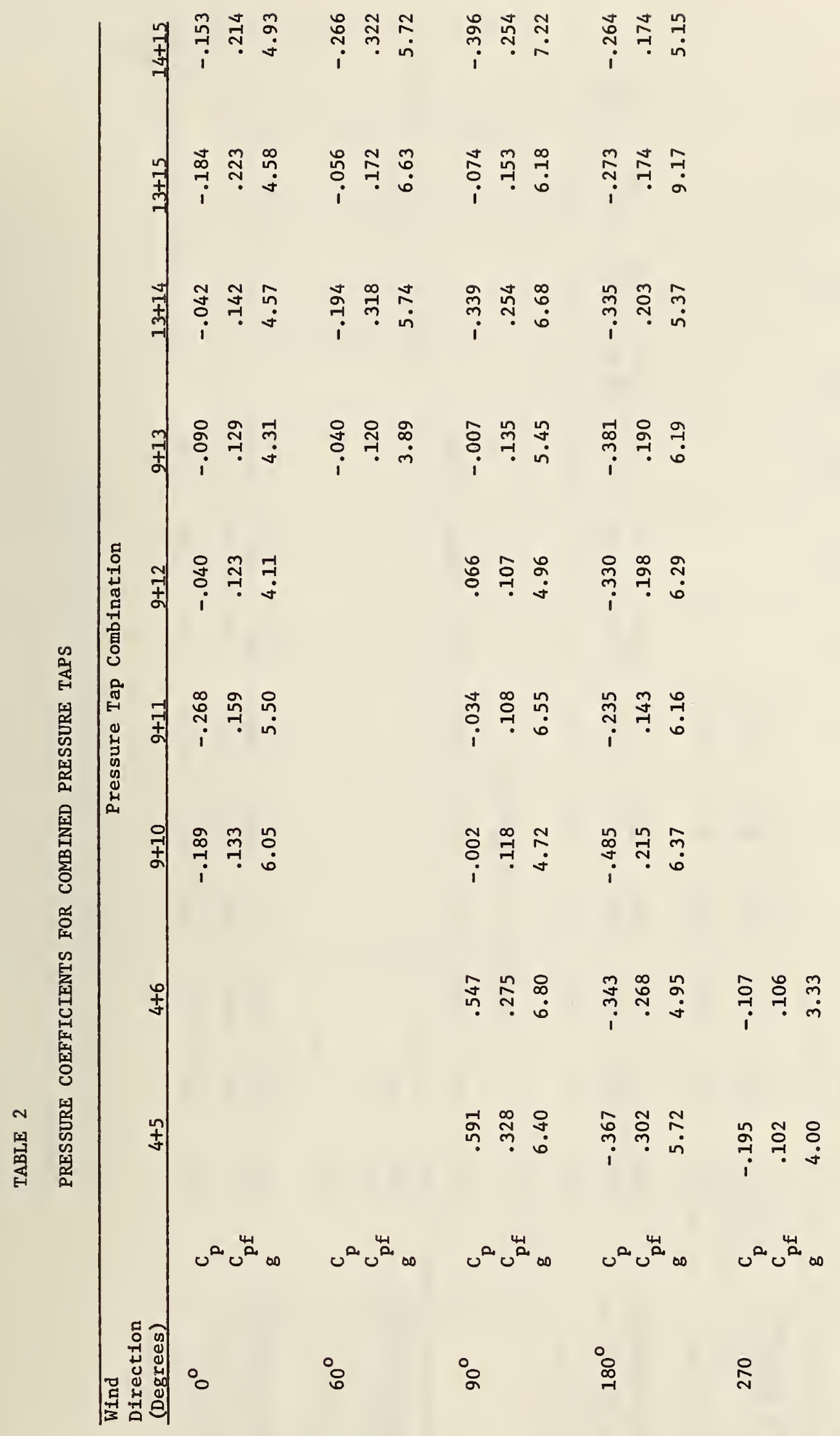




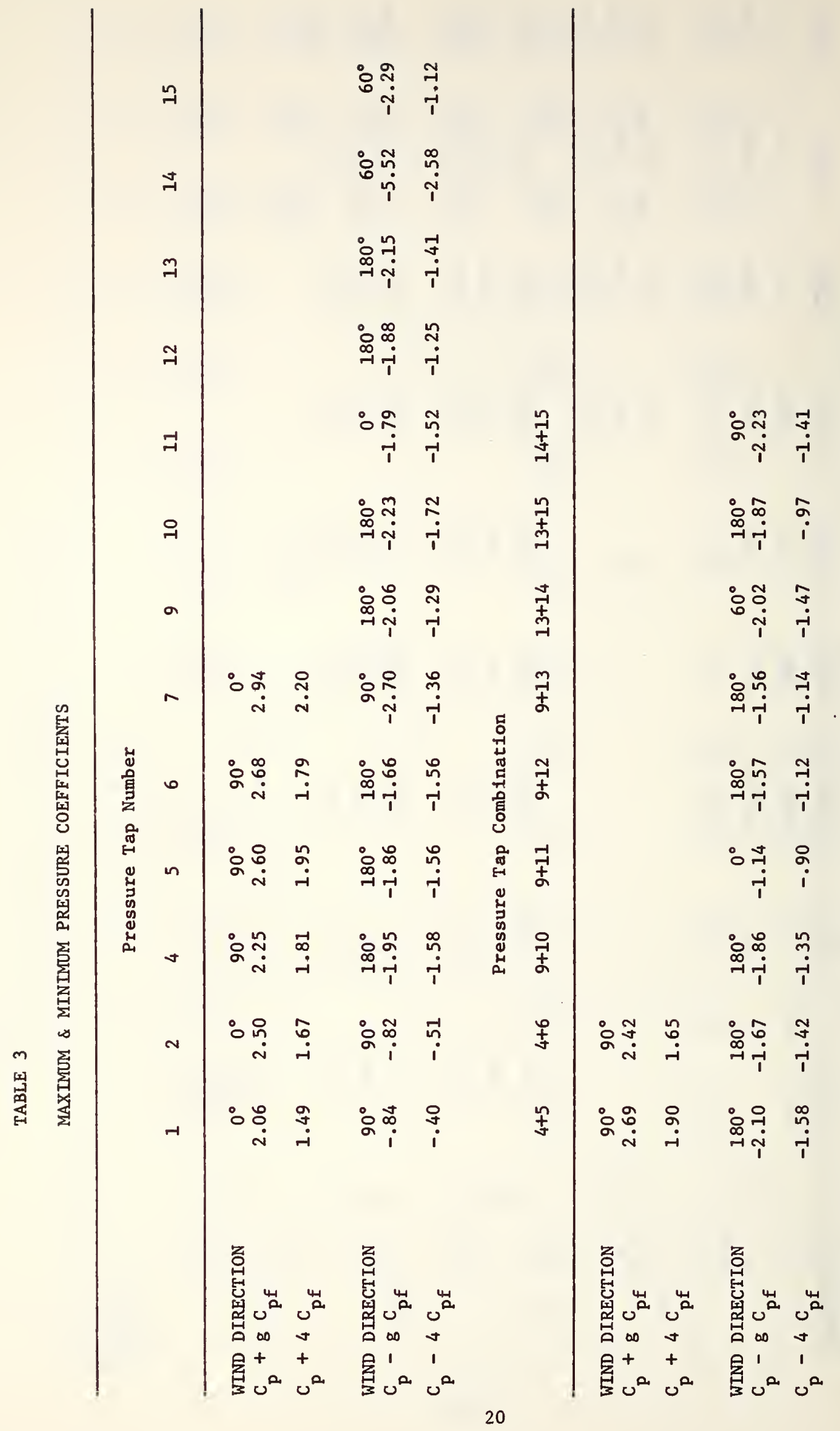




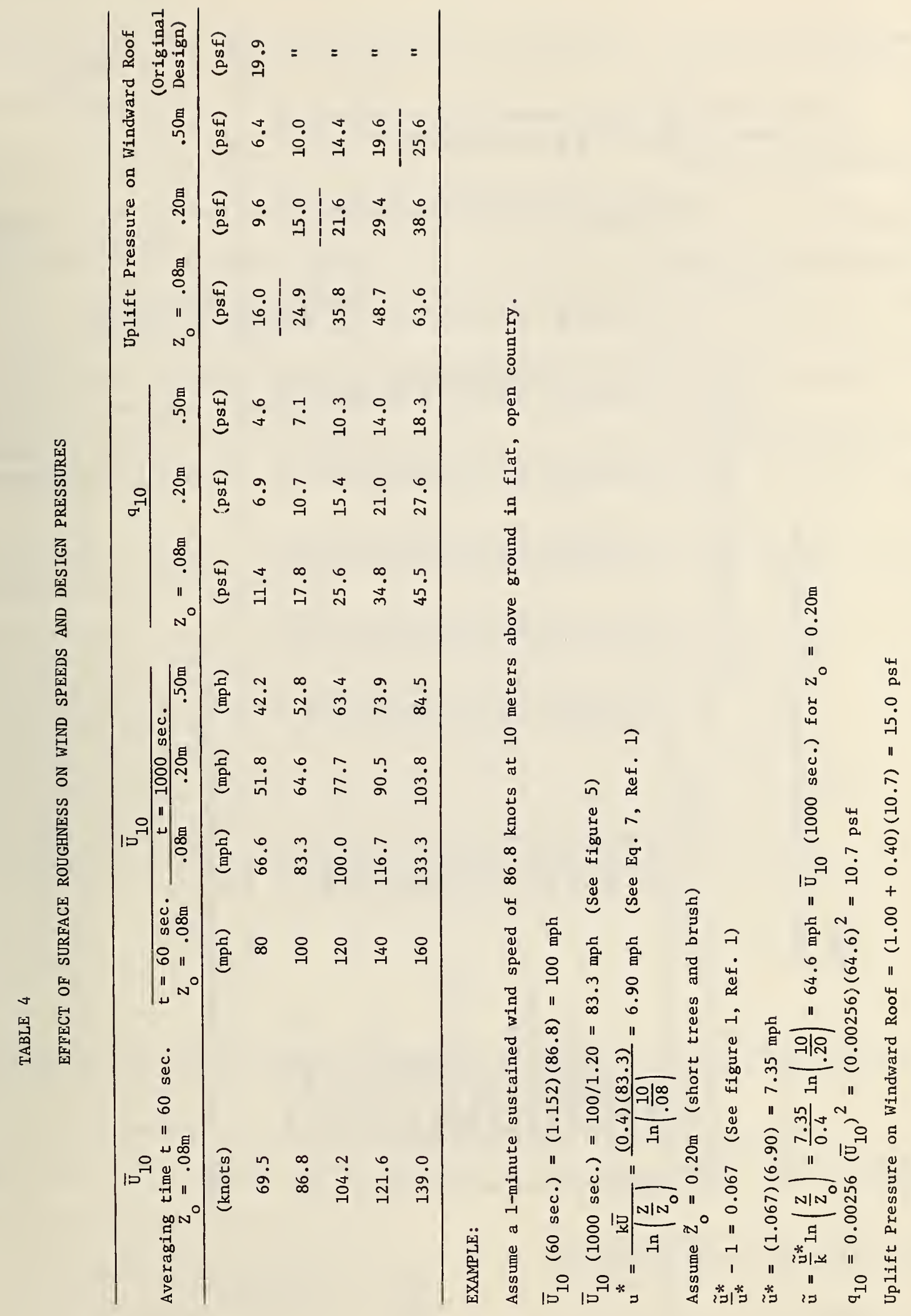




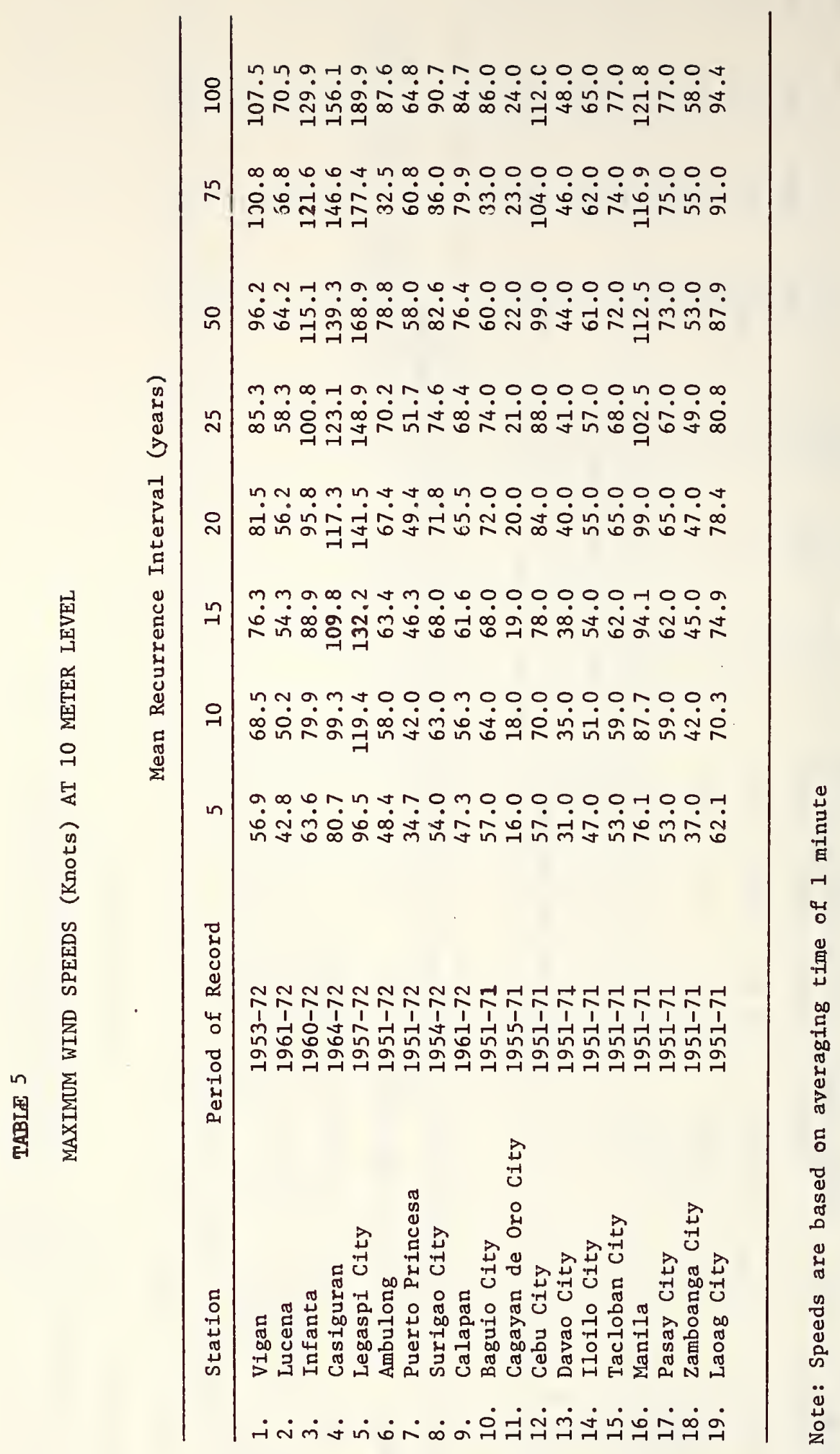




U.S. DEPT. OF COMM.
BIBLIOGRAPHIC DATA
SHEET

4. TITLE AND SUBTITLE
1. PUIBLIC.ATION OR RI:PORT NO.

NBSIR $77-1196$

Wind Tunnel Studies of RP-US Bayanihan Permanent School

Building

7. AUTHOR(S)

Richard D. Marshall

9. PERFORMING ORGANIZATION NAME AND ADDRESS

\section{NATIONAL BUREAU OF STANDARDS \\ DEPARTMENT OF COMMERCE \\ WASHINGTON, D.C. 20234}

12. Sponsoring Organization Name and Complete Address (Street, City, State, ZIP)

Office of Science and Technology

Agency for International Development

Department of State

Wrehington D. C. 20523.

15. SUPPLEMENTARY NOTES

16. ABSTRACT (A 200-word or less factual summary of most significant information. If document includes a significant bibliography or literature survey, mention it here.)

Wind pressures measured on a 1:80 scale model of the RP-US Bayanihan Permanent School Building are compared with wind pressures used in the original design calculations. The wind tunnel studies were conducted in a tunnel fitted with spires and roughness elements to generate a thick, turbulent boundary layer. This boundary layer is believed to be a reasonable simulation of the lowest portion of the atmospheric surface layer developed over rolling countryside with scattered trees or over suburban areas. While the wind tunnel test results are in fair agreement with the overall design wind pressures, edges of the roof along the end walls can be subjected to pressures which substantially exceed the design values. It is recommended that the load capacity of certain roof elements be reexamined and that ridge ventilators be used in future construction to reduce the uplift loads on the roof structure.

17. KEY WORDS (six to twelve entries; alphabetical order; capitalize only the first letter of the first key word unless a proper name; separated by semicolons)

Aerodynamics; boundary layers; buildings; turbulence; wind loads; wind tunnels

\begin{tabular}{|c|c|c|}
\hline $\begin{array}{l}\text { 18. AVAILABILITY }[\underset{\mathrm{X}}{ } \text { Unlimited } \\
\square \text { For Official Distribution. Do Not Release to NTIS }\end{array}$ & $\begin{array}{l}\text { 19. SECURITY CLASS } \\
\text { (THIS REPURT) } \\
\text { UNCL ASSIFIED }\end{array}$ & $\begin{array}{l}\text { 21. NO. OF PAGES } \\
27\end{array}$ \\
\hline $\begin{array}{l}\square \text { Order From Sup. of Doc., U.S. Government Printing Office } \\
\text { Washington, D.C. 20402, SD Cat. No. C13 }\end{array}$ & $\begin{array}{l}\text { 20. SECURITY CLASS } \\
\text { (THIS PAGE) }\end{array}$ & 22. Price \\
\hline $\begin{array}{l}\text { X Order From National Technical Information Service (NTIS) } \\
\text { Springfield, Virginia } 22151\end{array}$ & UNCLASSIFIED & $\$ 4.50$ \\
\hline
\end{tabular}


